\title{
Crises Management for Goal Attainment in Public Secondary Schools in Bonny, Rivers State: Importance of Planning
}

\author{
Adanma Ngozi Ohia, PhD \\ Department of Educational Management, Faculty of Education, \\ University of Port Harcourt, Rivers State, Nigeria
}

\begin{abstract}
This study examined how crises can be managed in public secondary schools in Bonny Local Government Area of Rivers State, Nigeria. Two research questions guided the study which adopted descriptive survey design. The sample was 150 staff made up of 134 teachers and 16 principals, census sampling technique was used. A researcherstructured instrument titled "Crises Management for Goal Attainment Questionnaire" (CMGAQ), was used to collect data. Three experts in the area of measurement and evaluation validated the instrument. The reliability was established using Pearson Product Moment Correlation which yielded a reliability index of 0.89 . The research questions were answered using mean and standard deviation. Findings showed effective planning, free flow of communication and joint problem-solving as being important in crises management. Recommendations include the need for principals to plan ahead how to avert crises, use good communication skills in managing crises including ensuring the existence of good relationship between the school and the host community.
\end{abstract}

Keywords: Crises management, goal attainment, public secondary schools, importance of planning

\section{INTRODUCTION}

All human activities are prone to crises of diverse nature and secondary schools being one of the important educational institutions made up of mostly youths are more vulnerable. Sessa (2006) described crisis as a rational and inevitable part of people working together. Even Bernstein (n.d.) observed the vulnerability of any organisation to crises and the school is inclusive. Good education is a panacea to eradicating illiteracy, ignorance and poverty from the society; and attaining the educational goals depends greatly on how well the school is free from crises that may erupt among the human entities in school, for instance, the principal, staff and students. The host community and neighbouring school communities may also be affected by the school community crises. Of course these crises affect negatively the smooth running of school programmes hence impinging on the attainment of stated goals. This gives credence to the importance of planning for crises management in secondary schools in order to enhance goal attainment.

In Nigeria, secondary education is the second level in her education system. The Federal Republic of Nigeria, in her National Policy on Education (FRN, 2004) explained that this is the education children receive after primary education and before tertiary education. Secondary school serves as a stepping stone to higher education and also responsible for the production of middle manpower in the overall economy. This actually provides opportunities for primary school leavers to acquire more knowledge, develop their skills and prepare to either enter tertiary institutions or explore the possibilities to acquire practical skills that will make them be self-reliant and eventual employers of labour. A crises-free school environment is germane for the attainment of these goals and the principal, as the head of administration in a secondary 
has to plan and ensure non-interruption of school programmes including teaching and learning process by crises.

Crises in the school system can retard greatly the progress towards attaining stated educational goals. Therefore the principal has to plan ab initio how to manage crises by exploring some strategies which include good communication system and joint problemsolving method. School crises management is a process the school organization uses to deal with events that threaten the stability of the school, its members and neigbouring communities. Being able to manage crises is hinged greatly on the principal's ability to do much practical planning prior to the incidence of any crises so as to best position both the principal and others in the school to respond quickly to and mitigate the situation (Adeyemi, 2009). Corroborating, Albert (2010) asserted that a good safety plan places emphasis on preventing any incidence of crises planning to improve students' behaviour, good policy implementation and organizing programmes that will create a friendly and safe school climate. The importance of good communication flow in averting crises or managing crises when they come up cannot be overemphasized. Bernstein (n.d.) while examining crises managementrelated plans in the process of a vulnerability audit found out that there is often a failure in addressing some crises-related communication issues in organisations; asserting that when there is inadequate communication, both internal and external, it could lead to, among other things, a breakdown in operational response. The principal as the organizational head in the school needs to be aware of this. In communication planning, on a daily basis, the principal needs to use both formal and informal communication skills. To buttress this, a study by Ajai (2017) in assessing conflict management strategies in public secondary schools in Delta State identified poor communication as one of the major causes of crises in schools. Of course, resolving the crises involved among other things, a free flow of communication among administration, staff and students.

Crises management plan in schools also needs a functional joint problem solving machinery. According to Alabi (2010) joint problem-solving is one conflict and crises management strategy. The principal therefore needs to explore all avenues in managing crises in the school by always involving all relevant groups which may include staff, students and even parents. Alabi (2010) opined that there might be the need to involve a neutral person or group often referred to as a mediator, expressing the relevance of mediation and negotiations in crises management. Using relevant persons to get first-hand information in crises management is important. Herein lies the importance of allowing for good representations of students, ParentTeachers Associations (P.T.A.) and the used of dialogue with school community members. All these depend on the nature of the crises. Incidentally a study by Adeyemi (2009) on principals' crises management in public secondary schools in Ondo state, Nigeria, seems to reveal the inadequate effective management of crises due to non-utilization of crises-resolving strategies. The study recommended that principals should use committees, communication, and other channels effectively.

\section{Statement of the Problem}

There seem to be recurrent incidents of crises among students in public secondary schools. This could be due to many reasons some of which include inadequate supply or even nonexistence of needed school amenities. Could it be that principals or school administrators do not plan ahead to avert or manage to the barest minimum the incidences of crises in schools by using some crises management strategies? This is the problem of this study. 


\section{Purpose of the study}

The main purpose of this study is to examine crises management strategies of principals in public secondary schools in Bonny Local Government Area. Specifically, the study sought how to use:

- Good communication flow as a strategy in planned crises management for goal attainment in public secondary schools.

- Joint problem-solving as a strategy in crises management for goal attainment in public secondary schools.

\section{Research Questions}

The following research questions guided the study:

- How can principals' communication strategies help in resolving crises for goal attainment in public secondary schools in Bonny Local Government Area of Rivers State?

- How does joint problem-solving approach of principals help in resolving crises for goal attainment in public secondary schools in Bonny Local Government Area of Rivers State?

\section{METHOD}

The study adopted a descriptive survey research design. Population of the study consisted of one hundred and fifty (150) staff made up of 134 teachers and 16 principals in public secondary schools in Bonny Local Government Area in Rivers State, Nigeria. The sample size for the study comprised of the entire population as census sampling technique was used. A research-structured questionnaire titled, "Crises Management for Goal Attainment Questionnaire (CMGAQ)", was the instrument for data collection. The 11-item instrument was patterned after the modified Likert four-point scale. The research instrument was validated by three experts in the area of measurement and evaluation, Faculty of Education, University of Port Harcourt, Choba. Test-retest method was used to ascertain the reliability of the research instrument. Using the Pearson's Product Moment Correlation Statistics, a reliability index of 0.89 was obtained. The data were analysed using mean scores and standard deviation. 2.50 was used as the criterion mean, therefore mean scores above 2.50 were accepted while mean scores below 2.50 were rejected.

\section{RESULTS AND DISCUSSION}

Table 1: Mean and standard deviation scores of how principals' communication strategies help in resolving crises for goal attainment in public secondary schools in Bonny Local Government Area

\begin{tabular}{|c|l|c|c|c|}
\hline $\mathbf{S} / \mathbf{N}$ & \multicolumn{1}{|c|}{ Items } & Mean & SD & Decision \\
\hline 1 & $\begin{array}{l}\text { Allowing the free flow of communication can assist } \\
\text { in resolving crises. }\end{array}$ & 3.44 & 0.92 & Agreed \\
\hline 2 & $\begin{array}{l}\text { Sending relevant information to those involved can } \\
\text { help avert crises for goal attainment in school } \\
\text { administration. }\end{array}$ & 3.17 & 0.76 & Agreed \\
\hline 3 & $\begin{array}{l}\text { Sending law enforcement agents to calm situations } \\
\text { can assist in controlling crises. }\end{array}$ & 3.38 & 0.90 & Agreed \\
\hline 4 & $\begin{array}{l}\text { Informing school members of planned crises } \\
\text { management strategy will enhance goal attainment. }\end{array}$ & 3.21 & 0.84 & Agreed \\
\hline 5 & $\begin{array}{l}\text { Sending urgent information to stakeholders during } \\
\text { crises can help in crises management. }\end{array}$ & 2.41 & 0.76 & Disagreed \\
\hline & Grand Mean & 3.12 & & \\
\hline
\end{tabular}


The data presented in Table 1 show that the mean rating of the respondents on the five items specifically $1,2,3,4$ and 5 had mean values of 3.44, 3.17, 3.38, 3.21 and 2.41 respectively. The results indicate the respondents agree that items 1 to 4 can enhance principals' communication strategy in crises management as is shown by their mean values which are above the criterion mean of 2.50. Item 5 has a mean value of 2.41 which is below 2.50 and is disagreed as an effective communication strategy. Informing relevant stakeholders of planned crises management strategy ahead of time is very essential. This is in line with the assertion of Adeyemi (2009) that the ability to manage crises in secondary schools is hinged on the principals' ability to do much practical planning prior to the incidence of any crises. This is corroborated by Albert (2010) who emphasized the importance of having a good safety plan to prevent any incident of crises. The importance of communication is buttressed by the result of the audit investigation by Bernstein (n.d.); while the result of item number 5 is in line with the study of Ajai (2017) that allowing for free flow of communication on a daily basis is essential not just to hurriedly inform stakeholders only when crises erupt.

Table 2: Mean and standard deviation scores of how joint problem-solving approach helps in crises management for goal attainment in public secondary schools in Bonny Local Government Area

\begin{tabular}{|c|l|c|c|c|}
\hline S/N & \multicolumn{1}{|c|}{ Items } & Mean & SD & Decision \\
\hline 6 & Involving teachers can help in crises management. & 3.01 & 0.78 & Agreed \\
\hline 7 & $\begin{array}{l}\text { Involving students can help resolve the problem for } \\
\text { goal attainment. }\end{array}$ & 2.71 & 0.72 & Agreed \\
\hline 8 & $\begin{array}{l}\text { Involving prominent people in the community can } \\
\text { help solve crises for goal attainment }\end{array}$ & 2.71 & 0.72 & Agreed \\
\hline 9 & $\begin{array}{l}\text { Use of parent-teachers association can help resolve } \\
\text { crises for the attainment of educational goals. }\end{array}$ & 2.81 & 0.74 & Agreed \\
\hline 10 & $\begin{array}{l}\text { Punishing groups involved may not always help } \\
\text { resolve crises in school }\end{array}$ & 3.22 & 0.80 & Agreed \\
\hline 11 & $\begin{array}{l}\text { Principals working with the security agencies will } \\
\text { help resolve crises for goal attainment in public } \\
\text { secondary schools }\end{array}$ & 3.22 & 0.84 & Agreed \\
\hline & Grand Mean & 3.12 & & \\
\hline
\end{tabular}

Table 2 shows that the mean ratings of items 6 to 11 are all above 2.50 and are agreed to by the respondents that involving teachers, students, community members, parent-teachers association and principals working with security agencies are examples of joint problemsolving strategies that can be used in managing crises. The importance of using joint problemsolving approach in management of crises in secondary schools as shown in Table 2 is in consonance with the findings of Alabi (2010) who expressed the need to always explore all avenues in managing school crises by involving all relevant groups.

\section{CONCLUSION}

A crises-free school environment is germane for the attainment of stated educational goals. It is the principal's responsibility as the administrative head in the school to envisage crises which may be inevitable and plan for crises management strategies. The free flow of communication and the use of joint problem-solving strategies help in school crises management and ultimately enhances the attainment of stated goals. Planning ahead is essential to avert crises or reduce to the barest minimum otherwise widespread crises.

\section{RECOMMENDATIONS}

- Principals of secondary schools should always envisage and therefore have planned crises management strategies. 
- Principals should at all times ensure that there is unhindered communication flow among all the human entities in the school community.

- Principals should explore the benefits that accrue from joint problem solving strategy in crises management.

\section{References}

Adeyemi, T. 0. (2009). Causes, consequences and control of students' crises in public and private universities in Nigeria.Educational Research and Reviews, 4(4), 26-32.

Ajai, E. A. (2017). Assessment of conflict management strategies in public secondary schools in Delta State.International Journal of Research Studies in Management, 6(9), 99-115.

Alabi, A. O. (2010). Management of conflicts and crises in Nigeria: Educational planer's view. Current Research Journal of Social Sciences, 2(6), 311-315. Retrieved from https://www.researchgate.net>publication

Albert, A. O. (2010). Colonialism, labour migrations and indigene/setter conflicts in Nigeria.African Journal of Peace and Conflicts Studies, University of Ibadan Centre for Peace and Conflict Studies, 1(1), 91-117.

Bernstein, J. (n.d). The 10 steps of crisis communication. Retrieved from https://www.bernsteincrisismanagement.com

Federal Republic of Nigeria (2004). National Policy on Education (Revised). Lagos: Nigerian Educational Research and Development Council, NERDC.

Sessa, V. I. (2006).Using perspective talking to manage conflict and effects in teams.Journal of Applied Behavioural Science, 32(1), 101-115. 